\title{
Physiology of juvenile hydroids - High food availability mitigates stress responses of Hydractinia echinata to increasing seawater temperatures
}

\author{
Yvonne Eder $^{\mathrm{a}, \mathrm{b}, *}$, Daniel Tschink ${ }^{\mathrm{a}}$, Gabriele Gerlach ${ }^{\mathrm{a}, \mathrm{b}, \mathrm{c}, \mathrm{d}}$, Julia Strahl ${ }^{\mathrm{a}, \mathrm{c}}$ \\ a Institute of Biology and Environmental Sciences, Carl von Ossietzky University Oldenburg, Carl von Ossietzky Str. 9-11, 26111 Oldenburg, Germany \\ ${ }^{\mathbf{b}}$ Institute of Chemistry and Biology of the Marine Environment, Carl von Ossietzky University Oldenburg, Carl von Ossietzky Str. 9-11, 26111 Oldenburg, Germany \\ ${ }^{\mathrm{c}}$ Helmholtz Institute for Functional Marine Biodiversity Oldenburg (HIFMB), Ammerländer Heerstraße 231, 23129 Oldenburg, Germany \\ ${ }^{\mathrm{d}}$ Centre of Excellence for Coral Reef Studies and School of Marine and Tropical Biology, James Cook University, Queensland, Australia
}

\section{A R T I C L E I N F O}

\section{Keywords:}

Cnidaria

Phenotypic plasticity

Temperature stress

Food availability

Standard metabolic rate

Oxidative damage accumulation

\begin{abstract}
A B S T R A C T
Ocean warming due to climate change is predicted to profoundly affect marine ecosystems. These effects are expected to be intensified for shelf seas like the North Sea, where sea surface temperatures are predicted to increase $3{ }^{\circ} \mathrm{C}$ by 2100 . Increasing seawater temperature is suggested to alter physiological performance of benthic marine invertebrates, while predicted changes in ocean dynamics and primary production might limit nutrient availability. At present, the combined effect of temperature and nutrition stress on marine biota is largely understudied. We investigated physiological responses in highly polymorphic hydroids Hydractinia echinata from two locations in the North Sea in response to two temperatures $\left(18^{\circ} \mathrm{C}=\right.$ ambient, $21^{\circ} \mathrm{C}=$ increased) cross factored with two food regimes (high, low). After 50 days of experimental exposure, morphological (biomass), physiological (standard metabolic rate) and biochemical performance (contents of protein and protein carbonyl) was determined in juvenile hydroids. Reduced growth and low total protein contents combined with high standard metabolic rates and high protein carbonyl contents in $H$. echinata exposed to $21^{\circ} \mathrm{C} /$ low food compared to $18^{\circ} \mathrm{C} /$ high food point towards an energy deficiency in the former animals. Meanwhile, high food availability seems to mitigate negative effects of elevated temperature, as energy budgets were sufficient to maintain growth and to keep oxidative damage accumulation low at $21^{\circ} \mathrm{C} / \mathrm{high}$ food. Our results suggest that high nutrition will increase resilience in juvenile hydroids to seawater temperatures predicted for 2100 in the North Sea. This study illustrates that habitat energy availability is a major driver of species distribution ranges and should be considered in when predicting responses of marine invertebrates to future environmental stressors.
\end{abstract}

\section{Introduction}

Global climate change due to rising anthropogenic greenhouse gas emissions such as carbon dioxide $\left(\mathrm{CO}_{2}\right)$ is a major threat for marine ecosystems (IPCC, 2014). Since $1750, \mathrm{CO}_{2}$ concentrations increased by $40 \%$, leading to atmospheric and ocean warming $\left(0.11^{\circ} \mathrm{C}\right.$ per decade between 1970 and 2010; IPCC, 2014). By 2100, atmospheric $\mathrm{CO}_{2}$ concentrations and ocean temperatures are predicted to rise higher than ever recorded. Globally, sea surface temperatures (SST) are predicted to increase by $1.5-2{ }^{\circ} \mathrm{C}$ (IPCC, 2014), and in the North Sea by $3{ }^{\circ} \mathrm{C}$ (Schrum et al., 2016) due to topographic conditions of shelf sea areas (e.g., shallow depths, high tidal ranges, large scale intertidal zones).

Further, future climate change scenarios predict a decrease in marine primary ( $>6 \%$ since the early 1980 ) and secondary production in the northern Atlantic Ocean (Gregg et al., 2003), due to the influence of the North Atlantic Oscillation (Fromentin and Planque, 1996), as well as changes in ocean dynamics (e.g., wave action, storm events; Grabemann and Weisse, 2008; Woth et al., 2005). For example, the mean wave height of continuous waves in the North Sea is predicted to increase by up to $+18 \%$ by 2100 (Grabemann and Weisse, 2008) due to projected wind changes. Prey-capture success of sessile filter feeders is suggested to be highly affected by wave action (Sebens, 2002). As a result, higher waves in addition to a reduced food availability might limit feeding time and prey-capture success in benthic suspension feeders in the future.

It is strongly debated whether the potential for acclimation or adaption in marine organisms will cope with the rate of ecosystem changes (reviewed in Hoffmann and Sgro, 2011), which might be highly species specific. Evidence accumulates that ocean warming can drive species turnover (Hillebrand et al., 2010) influencing species

\footnotetext{
* Corresponding author at: Carl von Ossietzky University Oldenburg, Carl von Ossietzky Str. 9-11, 26111 Oldenburg, Germany.

E-mail address: yvonne.eder@uni-oldenburg.de (Y. Eder).
} 
specific changes in phenology and trophic mismatches (Edwards and Richardson, 2004). This might lead to shifts in ecological communities and ecosystems in the future. Marine organisms living in intertidal habitats tend to have wider tolerances and higher potentials for phenotypic plasticity due to larger (daily and seasonal) fluctuations in temperature, salinity and oxygen availability compared to those living in the subtidal. However, due to recent changes in environmental conditions (e.g., rising summer SST, lower nutrition; Puce et al., 2009) in intertidal zones, several studies have shown a decrease in ecosystem biodiversity but an increase of sessile organisms, leading to higher competition (Hawkins et al., 2009).

Numerous impacts of rising SST on marine biota are reported in the literature ranging from restricted physiological performance to reduced reproduction, growth and even survival (e.g., Chomsky et al., 2004b; Hofmann and Todgham, 2010). Higher seawater temperatures can alter the kinetics of biochemical processes and disrupt enzyme functions and cofactor binding in poikilothermic organisms, leading to increasing metabolic fluxes, and higher standard metabolic rates and increasing cell damage (Hofmann and Todgham, 2010). This in turn can induce higher production rates of harmful reactive oxygen species (ROS). In aerobic animal cells, ROS are mainly formed in the mitochondrial electron transport chain during the course of oxidative phosphorylation (Harman, 1956, 1972). Oxidative stress occurs in case of rising ROS production rates and/or an imbalance in the pro-oxidant/antioxidant ratio, which turn favours pro-oxidants and results in oxidative damage accumulation (e.g., protein carbonyls, Halliwell and Gutteridge, 1999).

In marine invertebrates, phenotypic plasticity - in other words, phenotypic changes of morphological, physiological, life history or behavioural traits based on the experienced environmental conditions and at a given genotype (Garland and Kelly, 2006; Pigliucci, 2005; Scheiner, 1993; West-Eberhard, 2003) - is an important strategy to withstand rapid environmental changes. For example, high morphological plasticity is an effective mechanism in scleractinian corals to cope with the heterogenic nature of the reef environment or with external environmental forces (e.g., differences in light, sedimentation, gravity, water flow, competition, Flot et al., 2011; Shaish et al., 2007; Todd, 2008). Another well-known example for acclimation by a high level of phenotypic plasticity is shown in plants, which can achieve optimal reproduction and growth according to different environmental conditions through structural and physiological modifications (Todd, 2008; Weaver and Kramer, 1932).

A well-studied model organism with a high polymorphic potential (e.g., morphological plasticity; Blackstone, 1998; Frank et al., 2001) is the hydroid Hydractinia echinata (Fleming, 1828). This colony forming species mostly encrusts gastropod shells inhabited by the hermit crab Pagurus bernhardus (Linnaeus, 1758). They occur in the intertidal ( $<1 \mathrm{~m}$ depth) as well as in the subtidal ( $>50 \mathrm{~m}$ depth) of the North Atlantic Ocean, including the North Sea. The colonies consist of different types of polyps with distinct functions - gastrozooids (feeding), gonozooids (sexual reproduction), dactylozooids and tentaculozooids (interaction / protection / capture of prey) - which are connected through a gastrovascular system (Frank et al., 2001). Before the age of 3 months, the colony consists of gastrozooids exclusively, while the other polyp types can be found, when they become sexual mature (Frank et al., 2001). Due to the high polymorphic potential, the different polyp types possess limited availability to convert into each other (Muiller, 1961) and the shape of the colonies is highly variable (runner like vs. sheet like, Blackstone, 1998), partly dependent on the external environmental conditions.

In a controlled aquarium experiment, we investigated both morphological and physiological plasticity of juvenile $H$. echinata colonies in response to different temperature and food regimes. The parental colonies of these juveniles originated either from the subtidal around Helgoland or the intertidal around Sylt in the German Bight. Juveniles from Helgoland and Sylt were exposed to ambient $\left(18^{\circ} \mathrm{C}\right)$ and high $\left(21^{\circ} \mathrm{C}\right)$ temperatures, the latter according to predicted summer SST by
2100 in the German Bight, cross-factored with two food regimes (high and low). In order to assess potentials for acclimation to future environmental conditions and to estimate energetic costs of phenotypic plasticity, we determined morphological (growth), biochemical (contents of proteins and protein carbonyls) and physiological (standard metabolic rates) traits in juvenile $H$. echinata after 50 days of experimental exposure. In this study, we investigated how nutrition can alter physiological performance to cope with thermal stress.

\section{Material \& methods}

\subsection{Collection of parental colonies}

As H. echinata are distributed in different habitats in the North Sea (intertidal and subtidal), 8-10 wildtype colonies of the hydroid growing on gastropod shells were sampled in April 2016 at two different locations within the German Bight. Staff of the Alfred Wegener Institute collected animals i. at a depth of around $50 \mathrm{~m}$ (subtidal) at Helgoland $\left(54^{\circ} 07^{\prime}-54^{\circ} 15^{\prime} \mathrm{N} ; 07^{\circ} 48^{\prime}-07^{\circ} 57^{\prime}\right.$ E) using the research vessel Uthörn and ii. at a depth of $1-3.5 \mathrm{~m}$ (intertidal) at Sylt $\left(55^{\circ} 02^{\prime} \mathrm{N}\right.$; $\left.08^{\circ} 28^{\prime} \mathrm{E}\right)$ using the research vessel MYA II. Gastropod shells colonized by living H. echinata colonies from Helgoland and Sylt were shipped to the University of Oldenburg; hermit crabs (Pagurus bernhardus) inhabiting the shells had been removed. At Helgoland, the annual sea surface temperature (SST) ranges from $-1{ }^{\circ} \mathrm{C}$ to $19^{\circ} \mathrm{C}$ and the salinity ranges from 30.8-33.5 (Becker et al., 1997). Around Sylt, the mean annual SST is $+1{ }^{\circ} \mathrm{C}$ higher compared to Helgoland and ranges from $1{ }^{\circ} \mathrm{C}$ to $20^{\circ} \mathrm{C}$ (Musat et al., 2006), while salinity ranges from 25 to 33 (Hickel, 1980). In contrast to Helgoland with solid, rocky seabed, the seabed of Sylt is dominated by sand flats. The hydroids were transported to the University of Oldenburg, and cultured in artificial seawater (Aqua Medic, Germany) at $12{ }^{\circ} \mathrm{C}$ and a salinity of 34 . The colonies were fed daily with two-day old living Artemia salina nauplii.

\subsection{Reproduction \& larval settlement}

Following the Helgoland manual of animal development (Plickert, 2013), spawning in $H$. echinata colonies was induced by an artificial light source $(12 / 12 \mathrm{~h}$ light/dark cycle, $10.8 \pm 3.5 \mu \mathrm{mol}$ photons $\mathrm{m}^{-2} \mathrm{~s}^{-1}$, T5 Razor, Giesemann, Germany). Wildtype colonies started to release eggs and sperm daily approximately one $h$ after the onset of light. Four $\mathrm{h}$ after spawning, fertilized eggs were collected and washed in a $70 \mu \mathrm{m}$ pore filter (Cell Strainers, Falcon ${ }^{\mathrm{TM}}$, Thermo Fisher Scientific, USA) and transferred into $100 \mathrm{ml}$ of autoclaved artificial seawater at $18^{\circ} \mathrm{C}$ and a salinity of 34 . After two days, fertilized eggs had transformed into planula larvae and were collected and rinsed in a $200 \mu \mathrm{m}$ pore filter (Luer, Süd-Laborbedarf GmbH, Germany).

The transformation of the planula larvae was induced by incubating them for $3 \mathrm{~h}$ in $116 \mathrm{mM}$ caesium chloride at $18^{\circ} \mathrm{C}$ following the protocol of Seipp et al. (2007). Larvae were then rinsed and transferred into a glass bowl containing artificial seawater and black glass tiles (dimensions $10 \mathrm{~mm} \times 10 \mathrm{~mm} \times 2 \mathrm{~mm}$, Mosaikstein $\mathrm{GmbH}$, Germany) for settlement. Prior to the experiment, consecutive numbers were engraved at the bottom side of the glass tiles for identification (population and individual) of juvenile colonies during the experiment. Rates of survival of the juvenile colonies is low within the first two weeks (pers. comm. Daniel Tschink). Therefore, approximately 5 planula larvae were settled onto each plate to ensure the settlement of at least 2-3 larvae on each tile.

\subsection{Experimental setup}

Overall 300 glass tiles colonized by juvenile $H$. echinata were distributed randomly into 24 holding tanks $(100 \mathrm{ml}, 5-7$ glass tiles per tank and source population, Fig. 1). To be able to balance for tank specific effects, six replicate tanks were exposed to one of the four 


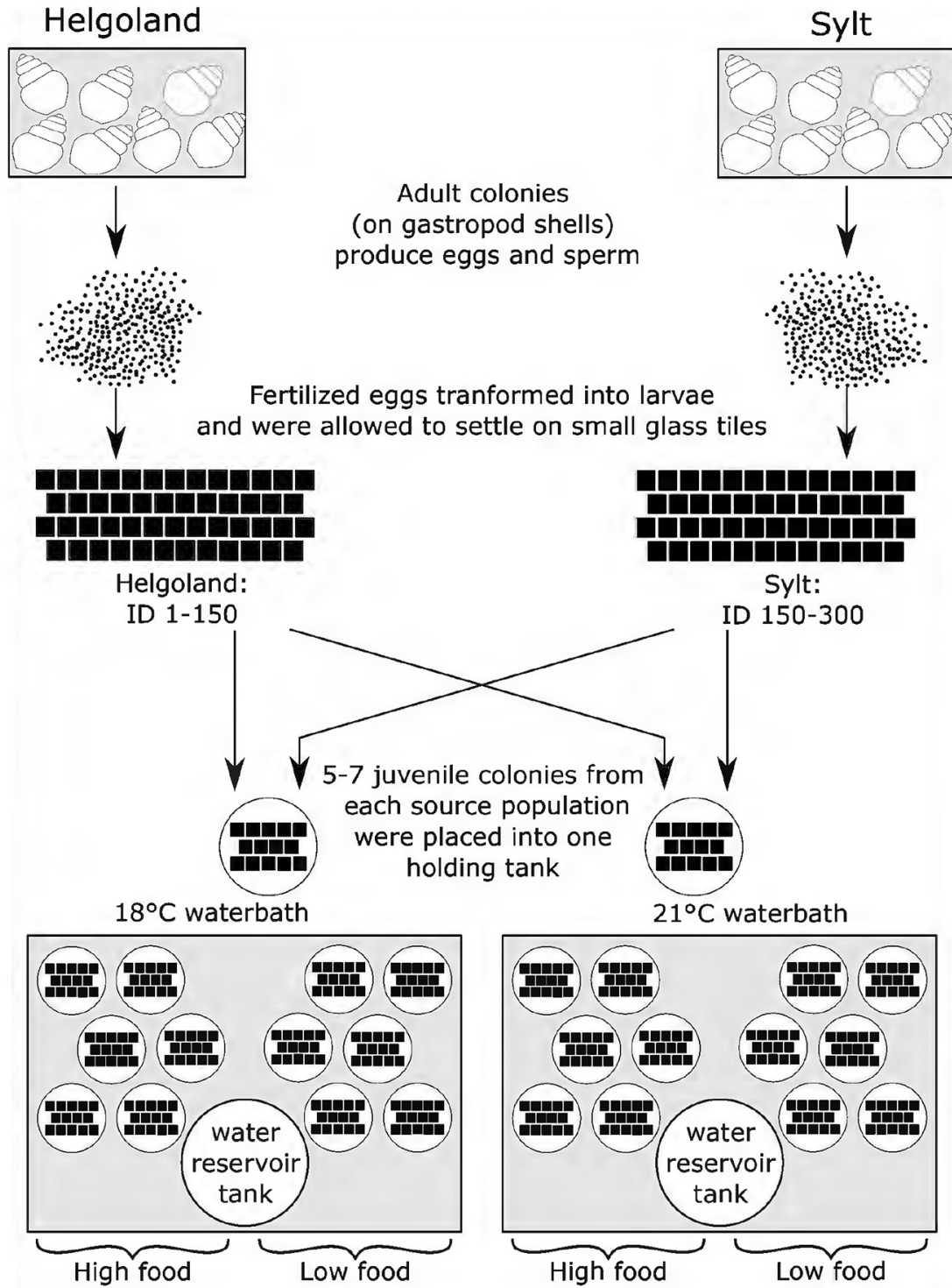

Fig. 1. Schematic diagram of the experimental design. Black glass tiles, with juvenile colonies were placed into 24 tanks (six tanks per treatment; five to six glass tiles of every source population in each tank (12 glass tiles per tank in total)). 24 replicate tanks containing the juvenile hydroids were placed in two water baths with either $18{ }^{\circ} \mathrm{C}$ or $21^{\circ} \mathrm{C}$. Half of the juveniles in each temperature treatment were fed three times a week (low food), and the other half five times a week (high food) with two-day old living A. salina nauplii. For 50 days juvenile $H$. echinata colonies were exposed to two different temperatures cross-factored with two different food conditions: $I=18{ }^{\circ} \mathrm{C} /$ high food; II $=18^{\circ} \mathrm{C} /$ low food; III $=21^{\circ} \mathrm{C}$ / high food; IV $=21{ }^{\circ} \mathrm{C} /$ low food.

12 of the replicate tanks ( 6 from each temperature) were provided with food 5 times a week, the remaining 3 times a week

\footnotetext{
Two reservoir tanks (one for each temperature) ensure no temperature fluctuations during water exchange events
}

experimental treatments (see below treatments I-IV, Fig. 1) for eight weeks. At day five post settlement, both Helgoland and Sylt juveniles were fed for the first time with two-day old living Artemia salina nauplii. After three weeks, the juvenile colonies growing closer to the edges were removed, to obtain one colony per tile.

Juvenile $H$. echinata colonies were exposed to two different temperatures cross-factored with two different food conditions: I. control temperature - high food $\left(18^{\circ} \mathrm{C} /\right.$ high food), II. control temperature - low food $\left(18^{\circ} \mathrm{C} /\right.$ low food), III. high temperature - high food $\left(21^{\circ} \mathrm{C} /\right.$ high food), IV. high temperature - low food $\left(21^{\circ} \mathrm{C} /\right.$ low food) (Fig. 1).

The control temperature of $18^{\circ} \mathrm{C}$ simulated the actual summer sea surface temperature (SST) in in the German Bight (data from Helgoland Roads, 2010-2014, http://www.st.nmfs.noaa.gov), while the high temperature of $21^{\circ} \mathrm{C}$ corresponded to the predicted increasing SST by the end of the century in the North Sea (IPCC, 2014). The tiles were placed in the holding tanks using tweezers without touching the colonies. The 24 replicate tanks containing the juvenile hydroids were placed in two water baths with water volumes of 401 covered with a glass plate in a frame of polystyrene to reduce evaporation and cooling. One thermostatic heater (Thermo control 300, Eheim, Germany) and two circulation pumps (Voyager NANO, Sicce, Italy) in each water baths kept temperatures constant at $18^{\circ} \mathrm{C}$ or $21^{\circ} \mathrm{C}(12$ tanks and a reservoir tank containing 21 of seawater in each water bath / temperature regime). Each replicate tank was provided with air through an air stone connected to a pump (HP-40, Hiblow, Japan). To evaluate the impact of food availability on the acclimatization potential in, half of the juveniles in each temperature treatment were fed three times a week (treatments II \& IV), and the other half five times a week (treatments I \& III) with two-day old living $A$. salina nauplii ( $>1000$ nauplii/ml per tank per feeding event). Since adult colonies were able to maintain their own metabolic needs and additionally were able to spawn daily at control temperatures when being fed 5 times a week (pers. comm. Daniel Tschink), we defined this regime as high food condition. The juvenile colonies were exposed to a $14 \mathrm{~h}$-light and $10 \mathrm{~h}$-dark cycle according to in situ summer (July/August) conditions in the German Bight. The conditions in treatment I-IV were monitored throughout the 
experiment. The temperature was constantly measured with a HOBO Tidbit v2 Temp Logger (Onset ${ }^{\circledR}$, USA) and the salinity was controlled prior to every water exchange ( $3 \mathrm{~h}$ after every feeding event) with a handheld refractometer (ARCARDA GmbH, Germany). Twice a week, the $\mathrm{pH}$ was measured with a $\mathrm{pH}$ controller (Aqua Medic, Germany), and concentrations of ammonium, nitrite and nitrate were monitored with test kits (JBL, Germany). Glass tiles were cleaned once a week without touching the colonies to minimize the influence of biofilm formation. This experimental design allowed us to assess the role of food availability on physiological performance of $H$. echinata under ambient and future seawater temperatures. An experimental duration of 50 days was chosen, because at this age, the juvenile colonies start to develop a layer containing chitin (pers. comm. Daniel Tschink). These morphological shifts might affect the physiological processes investigated in the present study, therefore the experiment was limited to 50 days.

\subsection{Morphological, biochemical and physiological analysis}

To be able to determine morphological parameters, oxygen consumption rate and total protein content for the same colonies, animals were used in a certain order. First, living animals were placed in the respiration chambers to measure individual oxygen consumption rates. Thereafter, the same animals were photographed individually for the analysis of polyp number and colony area (for details see method description and results in the supplement). Finally, the animals were scraped off the tiles (which kills the animals), weighed and snap frozen in liquid nitrogen to analyse biomass and total protein content. The remaining animals contained in the experimental tanks were snap frozen in liquid nitrogen to determine protein carbonyl content. Due to fewer fertilized eggs/larvae, more variable mortality rates and therefore lower number of colonies from Helgoland, the protein carbonyl content could only be determined in juveniles from Sylt.

\subsubsection{Respiration}

The oxygen $\left(\mathrm{O}_{2}\right)$ consumption rate as a proxy for standard metabolic rates was measured at the respective treatment temperature $\left(18^{\circ} \mathrm{C}\right.$ and $21^{\circ} \mathrm{C}$ ) following the protocol of Strahl et al. (2015). The colonies were placed individually in incubation chambers containing $2.9 \mathrm{ml}$ of $\mathrm{O}_{2}$ saturated artificial seawater. Magnetic glass stirrer in the bottom of each incubation chamber ensured continuous mixing $(500 \mathrm{rpm})$ of the seawater to avoid a build-up of an $\mathrm{O}_{2}$ concentration gradient. Colonies were incubated for approximately one hour in incubation chambers (including 15-20 min of acclimation time, which was excluded from the calculation of standard metabolic rates). They were kept in a water bath on top of a magnetic stir plate (Multi-point Magnetic Stirrer MS-MP8, Witeg, Germany). During incubation, $\mathrm{O}_{2}$ saturation was recorded every $15 \mathrm{~s}$ by a Multi-channel fibre optic oxygen transmitter system (Oxy-4Mini and associated software OXY-4 mini version 2.30FB, PreSens, Germany) connecting to oxygen sensor spots (PreSens, Germany) inside the chambers. After measurement, colonies were scraped off as described above and standard metabolic rates of colonies were calculated in $\mathrm{mg} \mathrm{O}_{2} \mathrm{~h}^{-1} \mathrm{mg}^{-1}$ biomass.

\subsubsection{Fresh weight}

The fresh weight was determined as a proxy for biomass. The colonies on the glass tiles were patted gently with a precision wipe (Kimtech science, Kimberly-Clark Professional, UK) to remove excess seawater. The glass tiles were weighed (weight A) with a precision balance (QUINTIX124-1S, Satorius, Germany), and individual colonies were scraped off the tiles with a surgical blade, transferred into Eppendorf tubes, weighed (weight B) and directly frozen at $-80^{\circ} \mathrm{C}$ for protein content determination. The tiles were cleaned and dried carefully, weighed again (weight $\mathrm{C}$ ); the net weight of the colony was calculated by subtraction of the weights A and C. The weight B was used for calculating of the total protein content, whereas the difference between weights $\mathrm{A}$ and $\mathrm{C}$ gave the exact weight of the colony, which was used for determining the oxygen consumption rate.

\subsubsection{Total protein content}

The total protein content as an indicator for energy storage capacity, was determined using the $\mathrm{DC}^{\mathrm{TM}}$ Protein Assay (Bio-Rad Laboratories, USA) based on the Lowry assay (Lowry et al., 1951). Both, a serial of diluted protein standards (Bovine Serum Albumin, Bio-Rad Laboratories) and hydroid samples were prepared referring to Leuzinger et al. (2003). The frozen colony tissues were diluted in $1 \mathrm{M} \mathrm{NaOH} \mathrm{1:80} \mathrm{(w:v).}$ Glass beads (diameter $0.1 \mathrm{~mm}$ ) were added and samples were vortexed (Vortex-Genie 2, Scientific Industries, Inc., USA) for 20-30 s and further homogenized on a rotating heating block (Thermomixer comfort, Eppendorf, Germany) for $20 \mathrm{~min}$ at $50{ }^{\circ} \mathrm{C}$ and $200 \times g$. These two steps were repeated three times, respectively. The sample homogenates were then centrifuged for $10 \mathrm{~min}$ at RT and $1500 \times g$ and the protein content of the supernatant was determined using the DC ${ }^{\mathrm{TM}}$ Protein Assay (BioRad Laboratories; Hercules, California, USA). Absorbance was measured at $750 \mathrm{~nm}$ with a microplate reader (Infinite $200^{\circledR}$ Pro, Tecan, Switzerland). Total protein content was calculated in $\mathrm{mg}$, referring to the standard curve.

\subsubsection{Protein carbonyls}

The protein carbonyl content, which is an indicator for production rates of harmful reactive oxygen species (ROS), was assessed in hydroids from Sylt by using an OxiSelect protein carbonyl enzyme-linked immunosorbent assay (ELISA) kit (Cell Biolabs, USA) according to the manufacturer's protocol. Briefly, samples (each tissue from one individual colony) were mixed with chilled $1 \times$ phosphate buffered saline (PBS, pH 7.4) at 1:50 (w/v) and homogenized in a MagNA Lyser Beadbeater (Roche Diagnostics, Germany) for $40 \mathrm{~s}$ at $5000 \mathrm{rpm}$. The homogenate was centrifuged for $3 \mathrm{~min}$ at $16100 \times \mathrm{g}$ and $4^{\circ} \mathrm{C}$, and the protein content of the supernatant was determined. The supernatant was diluted to $10 \mathrm{mg}$ protein $\mathrm{ml}^{-1}$ in $1 \times \mathrm{PBS}$, and protein carbonylbovine serum albumin standards were prepared. $100 \mathrm{ml}$ of sample or standard was transferred into wells of a 96-well protein binding plate and incubated overnight at $4{ }^{\circ} \mathrm{C}$. Subsequently, the samples were incubated for $45 \mathrm{~min}$ in 2,4-dinitrophenylhydrazine working solution and for $1.5 \mathrm{~h}$ in blocking solution. Immunodetection was performed using 2,4-dinitrophenol and horseradish peroxidase-conjugated antibodies provided by the manufacturer. Samples were incubated for $10 \mathrm{~min}$ in substrate solution before measuring the absorbance at $450 \mathrm{~nm}$ with a microplate reader (Infinite $200^{\circledR}$ Pro, Tecan, Switzerland). The protein carbonyl content of the samples was standardized to the protein content of the sample.

\subsubsection{Data analysis}

Since the treatments had cross-factored conditions, the effect of temperature, food availability and location was evaluated with a general linearized model (GLM). The distribution pattern of each dataset differed, so the GLM was fitted to each dataset and the respective distribution was tested with a Kolmogorov-Smirnov test (weight $=$ Poisson distribution; respiration rate $=$ binomial distribution; total protein content $=$ binomial distribution; protein carbonyls $=$ Gaussian distribution). The most parsimonious model was accomplished by backward elimination with a Chi-square test. Post-hoc pairwise Wilcoxon Rank Sum Test with a Bonferroni correction was performed to identify differences between the single treatments. Statistical analyses were conducted with R Studio (R Version 3.2.2., R Core Team (2016)). Since no tank effects were recorded in the replicate tanks, all colonies for each treatment and source population were pooled. The fresh weight, respiration rate and the total protein content was investigated in the same animals (Helgoland treatment I. $n=19$, II. $n=27$, III. $n=11$, IV. $n=14$; Sylt treatment I. $n=20$, II. $n=22$, III. $n=23$, IV. $n=16$ ). Due to high assay costs, animals were randomly selected out of each treatment from one source population to investigate the protein carbonyl content, (Sylt treatment I. $\mathrm{n}=16$, II. $n=13$, III. $n=12$, IV. $\mathrm{n}=13$ ). 

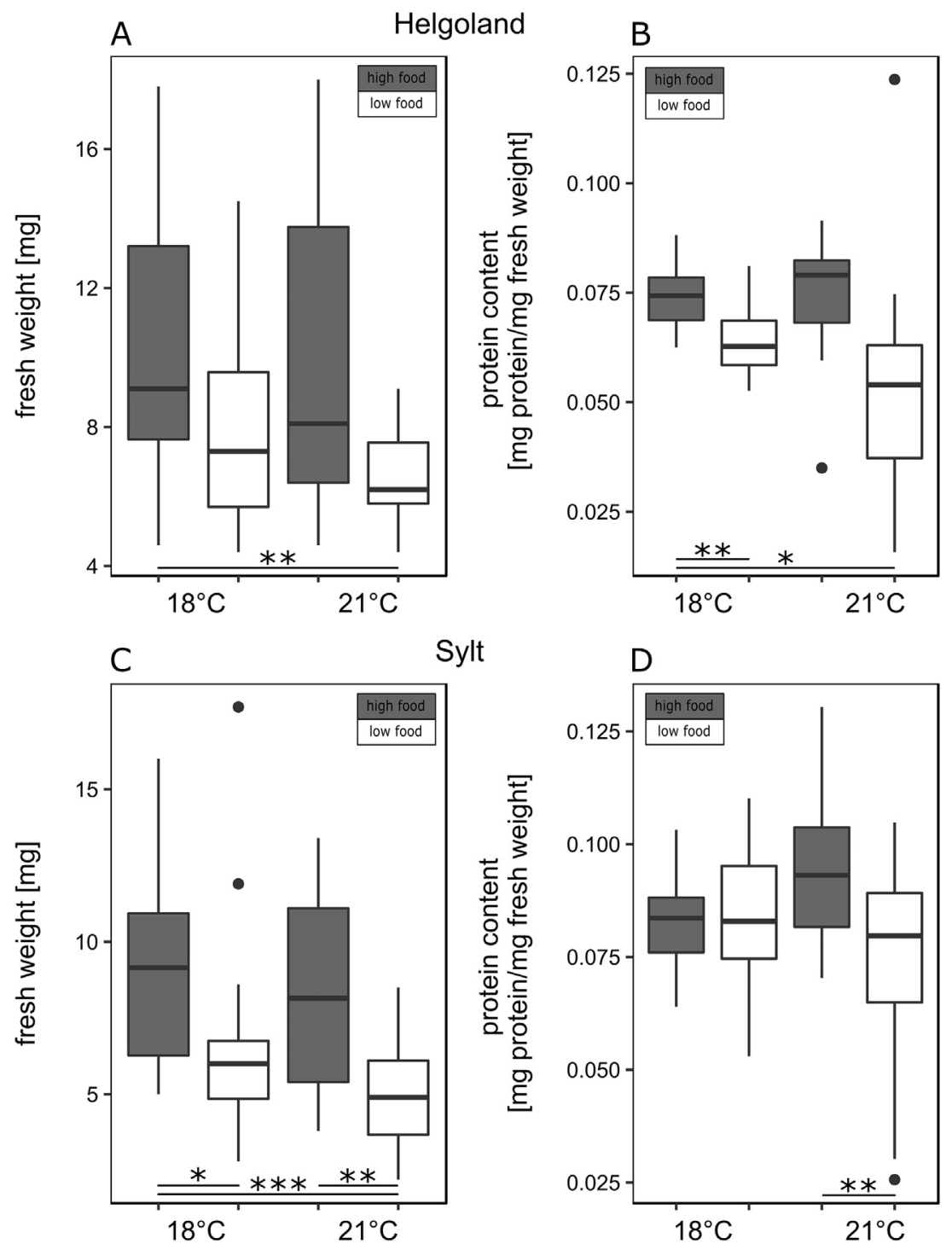

Sylt

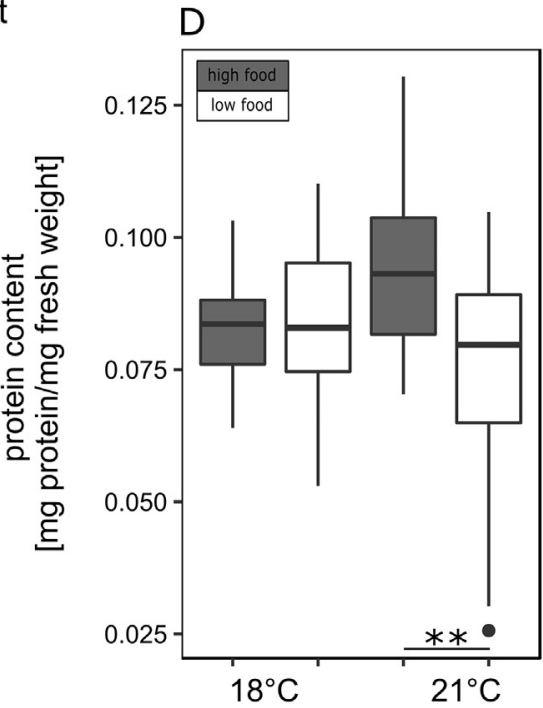

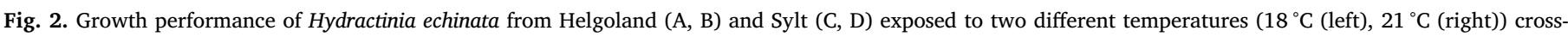

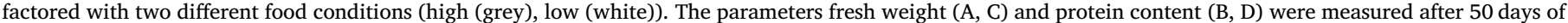

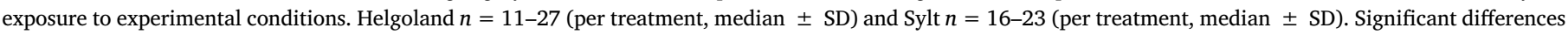
between single treatments (Mann-Whitney-U, ${ }^{*} p$-value $<.05$, ${ }^{* *}$ p-value $<.01$, ${ }^{* * *}$ p-value $<.001$ ).

\section{Results}

\subsection{Fresh weight}

The fresh weight of $H$. echinata colonies was significantly affected by food, temperature and location (Fig. 2, Table 1). The colonies exposed to $21{ }^{\circ} \mathrm{C} /$ low food were smaller compared to colonies from all other treatments. The mean fresh weight of colonies from Helgoland was $38 \%$ (Mann-Whitney-U, $p<.01$ ) and from Sylt 48\% (Mann-Whitney-U, $p<.001$ ) lighter in the $21^{\circ} \mathrm{C} /$ low food than in the $18^{\circ} /$ high food treatment (Fig. 2). Further, the colonies from Sylt in the $21^{\circ} \mathrm{C} /$ high food treatment were $41 \%$ heavier compared to those exposed to the $21^{\circ} \mathrm{C} /$ low food (Mann-Whitney-U, $p<.005$ ).

\subsection{Total protein content}

The total protein content of $H$. echinata colonies was significantly affected by location and the interaction between food and temperature (Fig. 2, Table 1). The colonies from Helgoland, had a 25\% lower total protein content at $21^{\circ} \mathrm{C} /$ low food and $14 \%$ lower total protein content at $18{ }^{\circ} \mathrm{C} /$ low food compared to colonies exposed to $18^{\circ} \mathrm{C} /$ high food conditions (Mann-Whitney-U, $p<.05$ ). For the colonies from Sylt, the mean total protein content was $21 \%$ higher in the colonies exposed to $21^{\circ} \mathrm{C} /$ high food compared to those exposed to the $21^{\circ} \mathrm{C} /$ low food treatment (Mann-Whitney-U, $\mathrm{p}<.05$ ).

\subsection{Respiration}

The respiration rate of $H$. echinata colonies was significantly affected by food, temperature and location (Fig. 3, Table 1). In colonies from both locations, the respiration rate of the colonies in the $18{ }^{\circ} \mathrm{C} / \mathrm{high}$ food treatment was $63 \%$ and $53 \%$ (Helgoland and Sylt, Mann-Whitney$\mathrm{U}, p<.002)$ lower than in those exposed to $21^{\circ} \mathrm{C} /$ low food. Furthermore, the respiration rate of the colonies from Sylt was $40 \%$ lower in the $21{ }^{\circ} \mathrm{C} /$ high food compared to the $21^{\circ} \mathrm{C} /$ low food treatment (MannWhitney-U, $p<.01$ ). In addition, the respiration rate of the colonies from Sylt was $35 \%$ lower in the $18{ }^{\circ} \mathrm{C} /$ high food compared to the $18{ }^{\circ} \mathrm{C} /$ low food treatment (Mann-Whitney-U, $p<.05$ ). This was supported by an additional data set relating the respiration rate to total protein content $\left[\mathrm{mg} \mathrm{O}_{2} / \mathrm{mg}\right.$ Protein/h] as an indicator for biomass (see 
Table 1

Statistical results. Effect of temperature and food on fresh weight, respiration and total protein content of $H$. echinata from Helgoland and Sylt and protein carbonyls of $H$. echinata from Sylt exposed to two different temperatures $\left(18^{\circ} \mathrm{C}\right.$, $21^{\circ} \mathrm{C}$ ) cross-factored with two food regimes (high, low). General linearized model; significant differences $(p<.05)$ are highlighted in bold; d.f. degrees of freedom.

\begin{tabular}{llll}
\hline & d.f. & $F$ & p-value \\
\hline Fresh weight & & & \\
Food & 156 & 27.4877 & $<.0001$ \\
Temperature & 157 & 5.4081 & $<.05$ \\
Location & 155 & 10.3206 & $<.01$ \\
Respiration & & & $<.0001$ \\
Food & 158 & 20.4860 & $<.05$ \\
Temperature & 159 & 5.8710 & $<.01$ \\
Location & 157 & 8.7384 & .35 \\
Total protein content & & & .69 \\
Food & 150 & 0.8644 & $<.05$ \\
Temperature & 151 & 0.1501 & $<.05$ \\
Location & 149 & 4.9276 & \\
Food:Temperature & 148 & 4.1667 & $<.01$ \\
Protein carbonyl content & & & $\mathbf{6 0 1}$ \\
Food & 50 & 7.5805 & \\
Temperature & 51 & 7.9136 & \\
Food:Temperature & 49 & 0.1791 & \\
\hline
\end{tabular}

supplement Fig. I, Table I), which showed similar trends.

\subsection{Protein carbonyls}

The protein carbonyl content in $H$. echinata from Sylt was significantly affected by food and temperature (Fig. 3, Table 1). Highest protein carbonyl contents were detected in colonies at $21^{\circ} \mathrm{C} /$ low food, while values were significantly lower $(-26 \%)$ at $18^{\circ} \mathrm{C} / \mathrm{high}$ food (Mann-Whitney-U, $p<.001$ ). Protein carbonyl contents were similar at $18{ }^{\circ} \mathrm{C} /$ low food and $21^{\circ} \mathrm{C} /$ high food.

\section{Discussion}

We investigated the effect of increased seawater temperature at different nutrition levels in juvenile $H$. echinata colonies, originated from Helgoland (subtidal) and Sylt (intertidal). To our knowledge, this is one of the first controlled aquarium studies adding defined food ratios to the experimental tanks when studying physiological responses in marine invertebrates to temperature stress. Our results suggest that food availability will significantly influence the resilience of hydroids to future environmental conditions, such as increasing seawater temperatures.

High nutrition seems to mitigate the effects of elevated temperature in $H$. echinata. When well fed, energy budgets of $H$. echinata were sufficient to maintain growth rates and protein contents at both temperatures, despite increasing metabolic and cell maintenance costs (e.g., up-regulation of cell protective capacities or protein turnover to 'recycle' protein carbonyls) at $21^{\circ} \mathrm{C}$. Our results are supported by earlier studies that suggested that high energy availability will increase the resilience of marine invertebrates to future climate change conditions (e.g., Han and Uye, 2010; Thomsen et al., 2013). Han and Uye (2010) showed that somatic growth increased with higher food availability under temperature stress in the scyphozoan Aurelia aurita. And Sokolova et al. (2012) stated that energy availability is directly linked to fitness-related functions such as development and growth in aquatic invertebrates and to their potential for acclimation to a broad range of environmental stressors. For example, high food availability mitigated acidification stress in marine bivalves. Thomsen et al. (2013) found seven times higher growth rates in the blue mussel Mytilus edulis at high acidic compared to low acidic conditions $\left(\mathrm{pCO}_{2} 1000 \mu\right.$ atm vs. 600 $\mu$ atm) in the Kiel fjord due to high nutrition. And in an experimental approach, growth in the blue mussel significantly decreased at low food concentrations and $\mathrm{CO}_{2}$ stress (Melzner et al., 2011). In two other studies anemones were observed to be more resilient to artificially induced hypoxic conditions when being able to feed on other, dying invertebrates (Stachowitsch et al., 2007; Riedel et al., 2014)., Our results and previous studies illustrate that food supply and habitat energy availability have to be taken into consideration when predicting responses of marine invertebrates to future environmental stressors.

In the present study, juvenile $H$. echinata were significantly affected by temperature stress at low food conditions. The reduced weight and the lower total protein content in colonies from Helgoland and Sylt exposed to $21^{\circ} \mathrm{C} /$ low food compared to those at the control temperature $\left(18^{\circ} \mathrm{C}\right)$ and high food regime point towards an energy deficiency in the former animals. Restricted growth rates under future environmental conditions (e.g., increasing SST and decreasing primary and secondary production in the North Atlantic, Gregg et al., 2003; IPCC, 2014) might reduce fitness in marine hydroids and benefit other competing ectosymbionts with a wider temperature tolerance window. In the present study, biomass rather than colony structure seem to be affected by high temperature and low food conditions, as experimental treatments had similar effects on area and polyp number of juvenile hydroids (see supplement Fig. II). In $H$. echinata, stressful temperature conditions seem to induce an energy allocation to more vital processes such as cell/tissue maintenance, while less energy is available to support growth and to maintain protein stores. For example, the total protein content in the Helgoland colonies decreased by $25 \%$ in the $21^{\circ} \mathrm{C} / \mathrm{low}$ food compared to the $18{ }^{\circ} \mathrm{C} /$ high food treatment. Accordingly, some field and laboratory studies showed that growth rates and total protein content in marine invertebrates decreased in response to high temperature and low food stress. Borell et al. (2008) and Bayne and Thompson (1970) reported this response in corals (Stylophora pistillata and Galaxea fascicularis) and in blue mussels and assumed that the breakdown of protein stores balanced increasing energetic demands at high seawater temperatures. Similarly, total protein contents in the soft coral Heteroxenia fuscescens declined at increasing seawater temperatures in the Red Sea between 1994 and 1998 (Ben-David-Zaslow and Benayahu, 1999). Two laboratory experiments with sea anemones Actinia equina showed that individuals exposed to either high temperatures $\left(25-30^{\circ} \mathrm{C}\right)$ or low feeding regime lost up to $50 \%$ of their body mass, in contrast to those exposed to ambient seawater temperatures $\left(15-20^{\circ} \mathrm{C}\right)$ or high nutrition (Chomsky et al., 2004a, 2004b). Also different field studies showed the coherence of food availability and the severity of stress responses in marine invertebrates, particularly to increasing seawater temperature. For example, a diverse epiphytic hydroid community showed a reduction in biomass during summer (Cunha and Jacobucci, 2010). Chomsky et al. (2004b) observed that the body size of adult Actinia equina decreased $\left(0.39 \%\right.$ day $\left.^{-1}\right)$ with increasing seawater temperature of $+3{ }^{\circ} \mathrm{C}$ in summer. In contrast, $A$. equina built-up energy reserves in spring and fall, probably due to the combined effects of lower environmental temperatures and higher food availability (e.g., due to plankton blooms, Chomsky et al., 2004a). This confirms our findings, where growth rates and protein contents were highest in $H$. echinata at $18{ }^{\circ} \mathrm{C} /$ high food.

The metabolic rate was inversely correlated to growth in hydroids from Helgoland and Sylt. This supports the hypothesis of an energy deficiency and energy allocation towards cell maintenance and repair in $H$. echinata exposed to temperature stress and low nutrition. Highest oxygen consumption rates were found in juvenile hydroids with lowest growth rates at $21^{\circ} \mathrm{C} /$ low food, while lower metabolic rates were found at $18{ }^{\circ} \mathrm{C}$. This is in agreement with the universal temperature dependence of metabolic rates in marine invertebrates (Newell, 1973). Nevertheless, food outweighed the temperature effect in the present study. At both $18{ }^{\circ} \mathrm{C}$ and $21{ }^{\circ} \mathrm{C}$, oxygen consumption rates were $22-55 \%$ higher in colonies at low compared to high nutrition, probably due to the utilization of all food components including lipids and the burning 

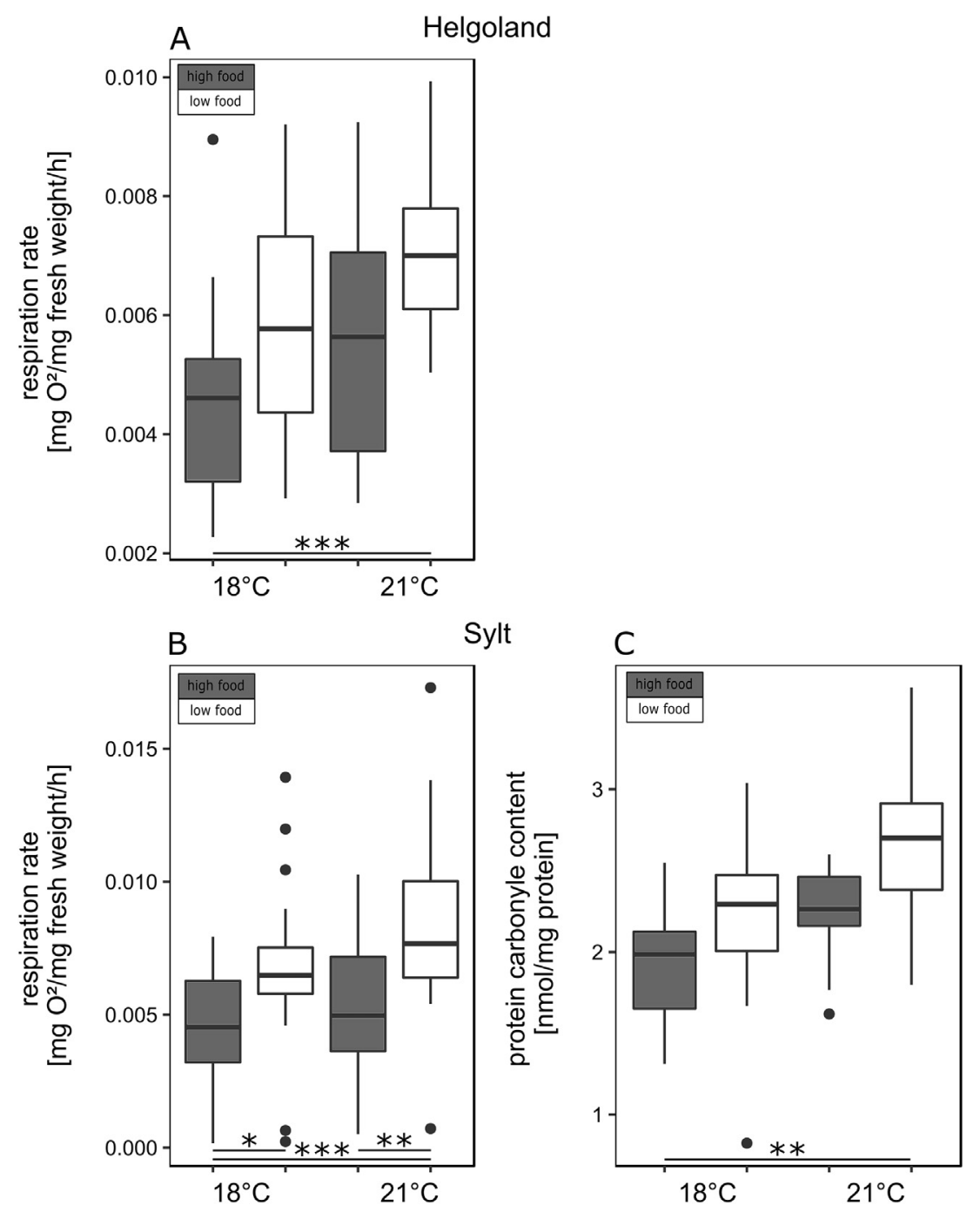

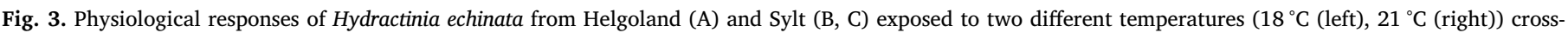

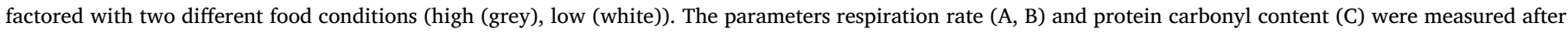

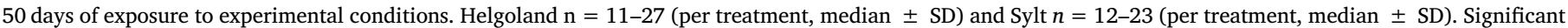
differences between single treatments (Mann-Whitney-U, ${ }^{*} p$-value $<.05$, ${ }^{* *}$ p-value $<.01,{ }^{* * *}$-value $<.001$ ).

of energy storages (e.g., lipids and proteins). The breakdown of lipids resulted in higher energy yields than that of proteins and carbohydrates, but it consumes more than twice the amount of oxygen needed for the oxidation of carbohydrate or protein (Schmidt-Nielsen, 1990). Our results suggest rising energetic requirements in $H$. echinata at low nutrition and elevated environmental temperatures, probably due to higher investment into cell maintenance and repairing task. Meanwhile, under high food conditions the primary use of proteins and carbohydrates (which consumes comparatively lower amounts of oxygen), might be sufficient to balance energy requirements in juvenile hydroids for somatic cell maintenance (e.g., cell protective capacities, protein turn over), as well as for tissue growth and maintaining protein stores. Correlations between the amount of oxygen consumption and the breakdown of major energy reserves (proteins, carbohydrates or lipids) have been previously observed in invertebrates (Selvan et al., 1993).

The protein carbonyl content in $H$. echinata mirrored the pattern of the respiration rate suggesting higher production rates of harmful reactive oxygen species (ROS) and the onset of oxidative stress at higher experimental temperature and high cellular oxygen turnover rates (e.g., highest rates of oxidative damage accumulation were found in juvenile hydroids exposed to the $21^{\circ} \mathrm{C} /$ low food). The correlation between high oxygen turnover and ROS formation was first proposed by Fleming et al. (1981) in the 'Free-Radical-Rate-of-living' theory and recently supported by several studies (e.g., Abele et al., 2009; Basova et al., 2012; Philipp et al., 2005; Richier et al., 2005). Furthermore, modifications of environmental conditions such as temperature and Ultra Violet Radiation are known to induce the reduction of oxygen into ROS, leading to protein oxidation, lipid peroxidation and DNA degradation (Halliwell and Gutteridge, 1999). For example, protein carbonyl contents and lipid peroxidation (= Malondialdehyde content) in sea anemones Anemonia viridis and Actinia schmidti increased three to tenfold under experimental exposure to hyperoxia $\left(100 \% \mathrm{O}_{2}\right)$ or thermal stress (elevated temperature $+7^{\circ} \mathrm{C}$ above normal, Richier et al., 2005). Here, elevated prooxidant conditions induced a depletion of antioxidant defences (e.g., superoxide dismutase activity) and cellular oxidative stress (Richier et al., 2005). Similarly, higher oxidative damage accumulation in juvenile $H$. echinata at low compared to high food conditions at the respective temperature can result either from a higher level of oxidative stress, and/or from a failure to repair or replace damaged biomolecules (Halliwell, 2006) due to a lack of energy. Thus, the combined effect of stressful temperature and nutrition induced highest protein carbonyl contents in hydroids observed at $21^{\circ} \mathrm{C} /$ low food. Meanwhile, oxidative damage accumulation was lower in hydroids in the high food treatments at both temperatures, probably due to higher energy availability 
and to the induction of cell protective capacities. It has been shown that cells are able to adapt to enhanced production rates of ROS by an upregulation of energy-consuming defence and/or repair systems (e.g., antioxidants or chaperons, Downs et al., 2002; Halliwell, 2006). For example, increasing seawater temperatures and UV radiation induced an up-regulation of homeostatic processes such as production of heatshock proteins and antioxidant enzymes in corals (Downs et al., 2013; Lesser, 1996; Suggett et al., 2008). Irreparable cellular damage by ROS can induce apoptotic or necrotic processes (Halliwell and Gutteridge, 1999), and chronic or repeated exposure to oxidative stress may decrease the fitness and genomic integrity of the individual and its offspring (Beckman and Ames 1998). On the other hand, researchers have suggested that some cnidarian species are 'immortal' due to high tissue renewal capacities and a lack of deteriorative processes associated with aging (reviewed in Martinez, 1998). Therefore, future studies should investigate whether additional adaptations in $H$. echinata to thermal stress such as an up-regulation of chaperons (e.g., heat shock proteins) and enzymatic activity.

The majority of morphological and physiological parameters determined in the present study showed similar treatment effects in juveniles originating from parental colonies from Helgoland (= subtidal) or Sylt (=intertidal). Nevertheless, slight differences between the two populations might be based on epigenetic acclimatization to different local environmental conditions. For example, the total protein content was higher in all treatments in offspring of the parental colonies from Sylt. This might be due to environmentally induced differences in percentage of the main body components (protein, lipids and carbohydrates) or in the soft-body-to-chitin-skeleton-ratio between the colonies. In the intertidal at Sylt, hydroids are exposed to higher fluctuations in temperature and salinity compared to the subtidal due to strong tides and the influence of the Elbe river (Hickel, 1980). While subtidal habitats at Helgoland are dominated by rocky substrate, mudflats and high contents of suspended sediment can be found in the intertidal at Sylt. It is already known, that environmental factors such as temperature contribute to DNA methylation variations ( $\mathrm{Pu}$ and Zhan, 2017) and alter gene expression, which could explain the observed location specific (Helgoland vs. Sylt) differences in biochemical parameters in $H$. echinata.

\section{Conclusion}

It is strongly debated whether the potential for acclimation in marine organisms will keep pace with the rate of ecosystem changes predicted for the future (reviewed in Hoffmann and Sgro, 2011). The results of the present study suggest, that food supply and habitat energy availability have to be taken into consideration when predicting responses of marine invertebrates to future environmental stressors. In agreement, recent studies about spatial species shifts identified habitat energy availability (e.g., phytoplankton abundance; Singer et al., 2016) as one of the major drivers of species distribution (e.g., Puce et al., 2009). Our results point towards an energy deficiency in $H$. echinata exposed to high temperature and low nutrition indicated by restricted growth, high rates of oxygen consumption and oxidative damage accumulation. On the other hand, high nutrition seems to mitigate the negative effects of stressful temperature conditions in juvenile hydroids. Energy budgets of $H$. echinata at $21^{\circ} \mathrm{C} /$ high food conditions were sufficient to maintain growth rates and protein store as well as cell protective and repair capacities. Thus, high nutrition will most likely improve potentials for physiological resilience in juvenile $H$. echinata to increasing seawater temperatures predicted for 2100 in the North Sea, whereas hydroids will suffer at low food availability. This suggests, that high energy availability will increase the resilience of marine invertebrates to future environmental conditions. The present study shows that physiological studies based on multi-factorial laboratory experiments will improve our understanding of species specific distribution limits and ecosystem shifts in the face of climate change.

\section{Acknowledgments}

We thank the team from the research vessel MYA II and the staff from AWI Sylt and Helgoland and the team from the research vessel Uthörn for the collection of the animals. A special thanks to Prof. Dr. em. Werner Müller (University Heidelberg), Prof. Dr. Günter Plickert (University Köln) and Prof. Dr. Uri Frank (University Galway) for their advice to culture the experimental animals. In addition, we thank the working group of Prof. Dr. Meinhard Simon (Institute for Chemistry and Biology of the Marine Environment, Oldenburg) for the opportunity to use their constant temperature container. We thank Dr. Gabrielle Miller and Dr. Philipp Krämer for sharing their scientific experience and Susanne Wallenstein and Anke Müller for their assistance in the laboratory. We thank Susan McMillan for improving the English text.

\section{Conflict of interest}

The authors declare that they have no conflict of interest.

\section{Funding}

This study is part of the collaborative Project MarBas (Marine Biodiversity across Scales) and the Research Training Group EcoMol (Ecology of Molecules) funded by the ministry of science and culture, Lower Saxony, Germany (MWK;" Nordwestallianz Meeresforschung und Meerestechnologien").

\section{Animal rights}

All applicable international, national and/or institutional guidelines for the care and use of animals were followed.

\section{Appendix A. Supplementary data}

Supplementary data to this article can be found online at https:// doi.org/10.1016/j.jembe.2018.07.009.

\section{References}

Abele, D., Brey, T., Philipp, E., 2009. Bivalve models of aging and the determination of molluscan lifespans. Exp. Gerontol. 44, 307-315.

Basova, L., Begum, S., Strahl, J., Sukhotin, A.A., Brey, T., Philipp, E., Abele, D., 2012. Age dependent patterns of antioxidants in Arctica islandica from six regionally separate populations with different life spans. Aquat. Biol. 14, 141-152.

Bayne, B.L., Thompson, R.J., 1970. Some physiological consequences of keeping Mytilus edulis in the laboratory. Helgoländer Meeresun. 20, 526-552.

Becker, G.A.F., Alexander, Damm, Peter, 1997. The northwest European shelf temperature and salinity variability. Deutsche Hydrographische Zeitschrift 49, 135-151.

Beckman, K.B., Ames, B.N., 1998. The Free Radical Theory of Aging Matures. Physiological Reviews 78, 547-581.

Ben-David-Zaslow, R., Benayahu, Y., 1999. Temporal variation in lipid, protein and carbohydrate content in the Red Sea soft coral Heteroxenia fuscescens. J. Mar. Biol. Assoc. U. K. 79, 1001-1006.

Blackstone, N.W., 1998. Physiological heterochrony and metabolic aspects of experimental in colonial hydroids. J. Evol. Biol. 11, 421-438.

Borell, E.M., Yuliantri, A.R., Bischof, K., Richter, C., 2008. The effect of heterotrophy on photosynthesis and tissue composition of two scleractinian corals under elevated temperature. J. Exp. Mar. Biol. Ecol. 364, 116-123.

Chomsky, O., Kamenir, Y., Hyams, M., Dubinsky, Z., Chadwick-Furman, N.E., 2004a. Effects of feeding regime on growth rate in the Mediterranean Sea anemone Actinia equina (Linnaeus). J. Exp. Mar. Biol. Ecol. 299, 217-229.

Chomsky, O., Kamenir, Y., Hyams, M., Dubinsky, Z., Chadwick-Furman, N.E., 2004b. Effects of temperature on growth rate and body size in the Mediterranean Sea anemone Actinia equina. J. Exp. Mar. Biol. Ecol. 313, 63-73.

Cunha, A.F., Jacobucci, G.B., 2010. Seasonal variation of epiphytic hydroids (Cnidaria: hydrozoa) associated to a subtropical Sargassum cymosum (Phaeophyta: Fucales) bed. Zoologia (Curitiba, Impresso) 27, 945-955.

Downs, C., Fauth, J., Halas, J., Dustan, P., Bemiss, J., Woodley, C., 2002. Oxidative stress and seasonal coral bleaching. Free Radic. Biol. Med. 33, 533-543.

Downs, C.A., McDougall, K.E., Woodley, C.M., Fauth, J.E., Richmond, R.H., Kushmaro, A., Gibb, S.W., Loya, Y., Ostrander, G.K., Kramarsky-Winter, E., 2013. Heat-stress and light-stress induce different cellular pathologies in the symbiotic Dinoflagellate during coral bleaching. PLoS One 8, 16.

Edwards, M., Richardson, A.J., 2004. Impact of climate change on marine pelagic 
phenology and trophic mismatch. Nature 430, 881-884.

Fleming, J., 1828. A History of British Animals, Exhibiting the Descriptive Characters and Systematical Arrangement of the Genera and Species of Quadrupeds, Birds, Reptiles, Fishes, Mollusca, and Radiata of the United Kingdom; Including the Indigenous, Extirpated, and Extinct Kinds, Together with Periodical and Occasional Visitants. Bell \& Bradfute, Edinburgh, pp. 1-565.

Fleming, J., Leon, H., Miquel, J., 1981. Effects of ethidium bromide on development and aging of Drosophila: implications for the free radical theory of aging. Exp. Gerontol. 16, 287-293.

Flot, J.-F., Blanchot, J., Charpy, L., Cruaud, C., Licuanan, W.Y., Nakano, Y., Payri, C., Tillier, S., 2011. Incongruence between morphotypes and genetically delimited species in the coral genus Stylophora: phenotypic plasticity, morphological convergence, morphological stasis or interspecific hybridization? Bio Med Central Ecol 11-22.

Frank, U., Leitz, T., Müller, W.A., 2001. The hydroid Hydractinia: a versatile, informative cnidarian representative. BioEssays 23, 963-971.

Fromentin, J.-M., Planque, B., 1996. Calanus and environment in the eastern North Atlantic. 11. Influence of the North Atlantic oscillation on C. finmarchicus and C. helgolandicus. Mar. Ecol. Prog. Ser. 134, 111-118.

Garland, T., Kelly, S.A., 2006. Phenotypic plasticity and experimental evolution. J. Exp. Biol. 209, 2344-2361.

Grabemann, I., Weisse, R., 2008. Climate change impact on extreme wave conditions in the North Sea: an ensemble study. Ocean Dyn. 58, 199-212.

Gregg, W.W., Conkright, M.E., Ginoux, P., O'Reilly, J.E., Casey, N.W., 2003. Ocean primary production and climate: global decadal changes. Geophys. Res. Lett. 30.

Halliwell, B., 2006. Reactive species and antioxidants. Redox biology is a fundamental theme of aerobic life. Plant Physiol. 141, 312-322.

Halliwell, B., Gutteridge, J.M., 1999. Free Radicals in Biology and Medicine, 3 ed. Oxford University Press, New York.

Han, C.-H., Uye, S.-I., 2010. Combined effects of food supply and temperature on asexual reproduction and somatic growth of polyps of the common jellyfish Aurelia aurita s.L. Plankon Benthos Res. 5, 98-105.

Harman, D., 1956. Aging: a theory based on free radical and radiation biology. J. Gerontol. 11, 298-300.

Harman, D., 1972. The biologic clock: the mitochondria? J. Am. Geriatr. Soc. 20, 145

Hawkins, S.J., Sugden, H.E., Mieszkowska, N., Moore, P.J., Poloczanska, E., Leaper, R., Herbert, R.J.H., Genner, M.J., Moschella, P.S., Thompson, R.C., Jenkins, S.R., Southward, A.J., Burrows, M.T., 2009. Consequences of climate-driven biodiversity changes for ecosystem functioning of North European rocky shores Marine Ecology Progress Series 396. pp. 245-259.

Hickel, W., 1980. The influence of Elbe River water on the Wadden Sea of Sylt (German bight, North Sea). Deutsche Hydrografische Zeitschrift 33, 43-52.

Hillebrand, H., Soininen, J., Snoeijs, P., 2010. Warming leads to higher species turnover in a coastal ecosystem. Glob. Chang. Biol. 16, 1181-1193.

Hoffmann, A.A., Sgro, C.M., 2011. Climate change and evolutionary adaptation. Nature 470, 479-485.

Hofmann, G.E., Todgham, A.E., 2010. Living in the now: physiological mechanisms to tolerate a rapidly changing environment. Annu. Rev. Physiol. 72, 127-145.

IPCC, 2014. Climate change 2014: synthesis report. contribution of working groups i, ii and iii to the fifth assessment report of the intergovernmental panel on climate change Core Writing Team. In: Pachauri, R.K., Meyer, L.., Core Writing Team (Eds.), Climate Change 2014: Synthesis Report. IPCC, Geneva, Switzerland (R.K. P.A.L.A.M.E $151 \mathrm{pp})$.

Lesser, M.P., 1996. Elevated temperatures and ultraviolet radiation cause oxidative stress and inhibit photosynthesis in symbiotic dinoflagellates. Limnol. Oceanogr. 41, 271-283.

Leuzinger, S., Anthony, K.R., Willis, B.L., 2003. Reproductive energy investment in corals: scaling with module size. Oecologia 136, 524-531.

Linnaeus, C., 1758. Systema Naturae per regna tria naturae, secundum classes, ordines, genera, species, cum characteribus, differentiis, synonymis, locis. Editio decima, reformata. Laurentius Salvius: Holmiae. ii, pp. 824.

Lowry, O.H., Rosebough, N.J., Randall, R.J., 1951. Protein measurement with the Folin phenol reagent. J. Biol. Chem. 193, 265-275.

Martinez, D.E., 1998. Mortality patterns suggest lack of senescence in hydra. Exp. Gerontol. 33, 217-225.

Melzner, F., Stange, P., Trubenbach, K., Thomsen, J., Casties, I., Panknin, U., Gorb, S.N., Gutowska, M.A., 2011. Food supply and seawater pCO2 impact calcification and internal shell dissolution in the blue mussel Mytilus edulis. PLoS One 6, e24223.

Müller, W., 1961. Untersuchung zur Stockdifferenzierung von Hydractinia echinata. Zoologische Jahrbücher 69, 317-324.

Musat, N., Werner, U., Knittel, K., Kolb, S., Dodenhof, T., van Beusekom, J.E., de Beer, D., Dubilier, N., Amann, R., 2006. Microbial community structure of sandy intertidal sediments in the North Sea, Sylt-Romo Basin, Wadden Sea. Syst. Appl. Microbiol. 29, $333-348$.

Newell, R.C., 1973. Factors affecting the respiration of intertidal invertebrates. Am. Zool 13, 513-528.

Philipp, E., Brey, T., Pörtner, H.-O., Abele, D., 2005. Chronological and physiological ageing in a polar and a temperate mud clam. Mech Age Dev 126, 589-609.

Pigliucci, M., 2005. Evolution of phenotypic plasticity: where are we now? Trends in Ecology and Evolution 20, 481-486.

Plickert, G., 2013. Developmental biology of the cnidarian Hydractinia. In: Fischer, A. (Ed.), The Helgoland Manual of Animal Development. Verlag Dr. Friedrich Pfeil, Germany.

Pu, C., Zhan, A., 2017. Epigenetic divergence of key genes associated with water temperature and salinity in a highly invasive model ascidian. Biol. Invasions 19, 2015-2028.

Puce, S., Bavestrello, G., Di Camillo, C.G., Boero, F., 2009. Long-term changes in hydroid (Cnidaria, hydrozoa) assemblages: effect of Mediterranean warming? Mar. Ecol. 30, 313-326.

R Core Team, 2016. In: Computing, R.F.F.S. (Ed.), R: A language and environment for statistical computing, (Vienna, Austria). http://www.R-project.org.

Richier, S., Furla, P., Plantivaux, A., Merle, P., Allemand, D., 2005. Symbiosis-induced adaptation to oxidative stress. J. Exp. Biol. 208, 277-285.

Riedel, B., Pados, T., Pretterebner, K., Schiemer, L., Steckbauer, A., Haselmair, A., Zuschin, M., Stachowitsch, M., 2014. Effect of hypoxia and anoxia on invertebrate behaviour: ecological perspectives from species to community level. Biogeosciences 11, 1491-1518.

Scheiner, S.M., 1993. Genetics and the evolution of phenotypic plasticity. Annu. Rev. Ecol. Syst. 24, 35-68.

Schmidt-Nielsen, K., 1990. Adaptation and environment. In: Animal Physiology. Cambridge University Press, Cambridge, pp. 240-295.

Schrum, C., Lowe, J., Meier, H.E.M., Grabemann, I., Holt, J., Mathis, M., Pohlmann, T., Skogen, M.D., Sterl, A., Wakelin, S., 2016. Projected Change-North Sea. In: Bolle, H.J., Menenti, Massimo, Rasool, S. Ichtiaque (Eds.), Regional Climate Studies, pp. $175-217$.

Sebens, K.P., 2002. Energetic constraints, size gradients, and size limits in benthic marine invertebrates. Integr. Comp. Biol. 42, 853-861.

Seipp, S., Schmich, J., Kehrwald, T., Leitz, T., 2007. Metamorphosis of Hydractinia echinata-natural versus artificial induction and developmental plasticity. Dev. Genes Evol. 217, 385-394.

Selvan, S., Gaugler, R., Lewis, E.E., 1993. Biochemical energy reserves of entomopathogenic nematodes. J. Parasitol. 79, 167-172.

Shaish, L., Abelson, A., Rinkevich, B., 2007. How plastic can phenotypic plasticity be? The branching coral Stylophora pistillata as a model system. PLoS One 2, e644.

Singer, A., Schückel, U., Beck, M., Bleich, O., Brumsack, H.J., Freund, H., Geimecke, C., Lettmann, K.A., Millat, G., Staneva, J., Vanselow, A., Westphal, H., Wolff, J.O., Wurpts, A., Kröncke, I., 2016. Small-scale benthos distribution modelling in a North Sea tidal basin in response to climatic and environmental changes (1970s-2009). Mar. Ecol. Prog. Ser. 551, 13-30.

Sokolova, I.M., Frederich, M., Bagwe, R., Lannig, G., Sukhotin, A.A., 2012. Energy homeostasis as an integrative tool for assessing limits of environmental stress tolerance in aquatic invertebrates. Mar. Environ. Res. 79, 1-15.

Stachowitsch, M., Riedel, B., Zuschin, M., Machan, R., 2007. Oxygen depletion and benthic mortalities: the first in situ experimental approach to documenting an elusive phenomenon. Limnol. Oceanogr. Methods 5, 344-352.

Strahl, J., Stolz, I., Uthicke, S., Vogel, N., Noonan, S.H., Fabricius, K.E., 2015. Physiological and ecological performance differs in four coral taxa at a volcanic carbon dioxide seep. Comparative biochemistry and physiology. Part A, Molecular \& integrative physiology 184, 179-186.

Suggett, D.J., Warner, M.E., Smith, D.J., Davey, P., Hennige, S., Baker, N.R., 2008. Photosynthesis and production of hydrogen peroxide by Symbiodinium (Pyrrhophyta) phylotypes with different thermal tolerances. J. Phycol. 44, 948-956.

Thomsen, J., Casties, I., Pansch, C., Kortzinger, A., Melzner, F., 2013. Food availability outweighs ocean acidification effects in juvenile Mytilus edulis: laboratory and field experiments. Glob. Chang. Biol. 19, 1017-1027.

Todd, P.A., 2008. Morphological plasticity in scleractinian corals. Biol. Rev. 83, 315-337.

Weaver, J.E., Kramer, J., 1932. Root system of Quercus macrocarpa in relation to the invasion of prairie. Bot. Gaz. 94, 51-85.

West-Eberhard, M.J., 2003. Developmental Plasticity and Evolution. Oxford University Press, Oxford.

Woth, K., Weisse, R., von Storch, H., 2005. Climate change and North Sea storm surge extremes: an ensemble study of storm surge extremes expected in a changed climate projected by four different regional climate models. Ocean Dyn. 56, 3-15. 